\title{
KONTRIBUSI INSTRUMEN MONETER SYARIAH TERHADAP PENGENDALIAN INFLASI DI INDONESIA
}

\author{
${ }^{1}$ Eva Misfah Bayuni, ${ }^{2}$ Popon Srisusilawati \\ ${ }^{1,2,}$ FakultasSyariah, Universitas Islam Bandung, Jl. Ranggagading No. 8 Bandung 40116 \\ email :'evambayuni@gmail.com ; ${ }^{2}$ po2nss@gmail.com
}

\begin{abstract}
Abstrak : Bank Indonesia menggunakan instrumen-instrumen moneter yang akan mencapai sasaran operasional yang berdampak pada sasaran utama kebijakan moneter di Indonesia yaitu inflasi.Sistem moneter ganda yang diterapkan di Indonesia, membuat instrumen-instrumen moneter konvensional berjalan beriringan dengan instrumen moneter syariah. Tujuan pada penelitian ini menjelaskan instrumen moneter menurut syariah di Indonesia dan mengetahui besaran kontribusi instrumen moneter dalam syariah terhadap pengendalian inflasi di Indonesia. Metode penelitian yang digunakan pada penelitian ini yaitu metode regresi simultan dengan menggunakan software Eviews 9. Hasil penelitian yang didapatkan; Pengendalian Inflasi di Indonesia menurut Syariah yaitu dengan menggunakan intrumen-instrumen moneter yang sesuai dengan industri perbankan syariah di Indonesia. Kontribusi instrumen-instrumen moneter syariah terhadap pengendalian inflasi di Indonesia masih sangat kecil. Hal ini berdasarkan hasil pengolahan pada penelitian ini bahwa instrumen moneter syariah hanya beberapa model yang berkontribusi. Nilai kontribusi yang dihasilkan pun sangat kecil dengan skala penilaian $R$ Squared berkisar sangat lemah dan atau lemah.
\end{abstract}

\section{Kata Kunci : Instrumen Moneter Syariah, Inflasi}

Abstract : Bank Indonesia uses monetary instruments that will achieve operational targets that impact the main targets of monetary policy in Indonesia, namely inflation. The dual monetary system implemented in Indonesia, making conventional monetary instruments go hand in hand with Sharia monetary instruments. The purpose of this research is to explain monetary instruments according to syariah in Indonesia and to know the magnitude of monetary instrument contribution in sharia against inflation control in Indonesia. The research method used in this research is simultaneous regression method by using software Eviews 9. Result of research obtained; Inflation Control in Indonesia according to Sharia is by using monetary instruments in accordance with the sharia banking industry in Indonesia. The contribution of sharia monetary instruments to inflation control in Indonesia is still very small. It is based on the results of processing in this study that syariah monetary instruments are only a few models that contribute. The resulting contribution value is very small with the Squared $\mathrm{R}$ scoring scale ranging from very weak and / or weak.

\section{Keywords: Sharia Monetary Instrument, Inflation}

\section{PENDAHULUAN}

Bank Indonesia (Bank Indonesia, 2015) sebagai otoritas moneter tertinggi di Indonesia memiliki tujuan untuk mencapai dan memelihara kestabilan nilai rupiah. Tujuan ini sebagaimana tercantum dalam
UU No. 3 tahun 2004 pasal 7 tentang Bank Indonesia.

Koordinasi juga dilakukan oleh Bank Indonesia dan Pemerintah untuk mengendalikan inflasi. Hal tersebut dapat dilihat pada gambar (Bank Indonesia, 2015) berikut ini:

Received: 2017-12-20 | Reviced: 2018-01-29 | Accepted: 2018-01-31

Indexed : DOAJ, Garuda, Crossref, Google Scholar | DOI : https://doi.org/10.29313/amwaluna.v2i1.3314 


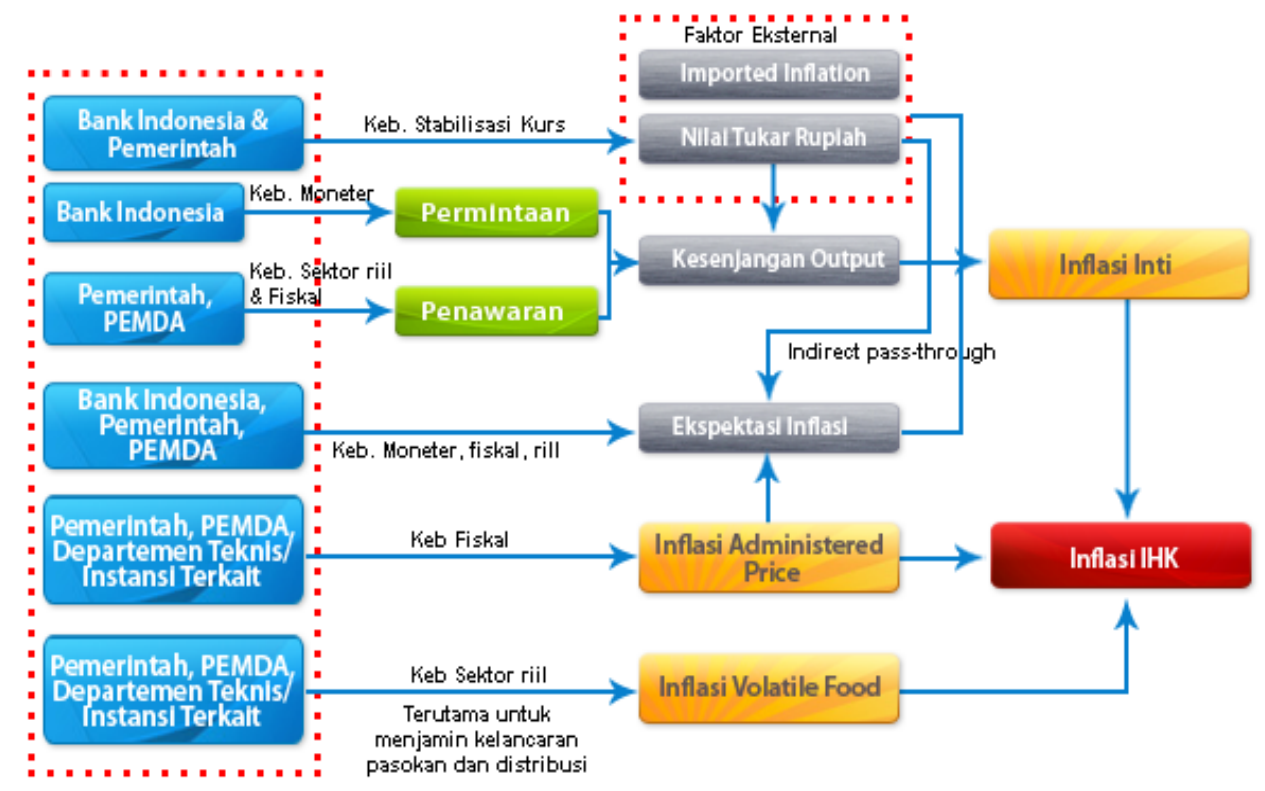

Gambar.1

\section{Koordinasi Pengendalian Inflasi di Indonesia}

Secara operasional, pengendalian sasaran-sasaran moneter tersebut menggunakan instrumen-instrumen, antara lain operasi pasar terbuka di pasar uang baik rupiah maupun valuta asing, penetapan tingkat diskonto, penetapan cadangan wajib minimum, dan pengaturan kredit atau pembiayaan. Bank Indonesia juga dapat melakukan cara-cara pengendalian moneter berdasarkan Prinsip Syariah (Bank Indonesia, 2015).

Adanya perbedaan prinsip antara ekonomi Islam dengan ekonomi konvensional yang terkait dengan masalah sistem bunga (pre-determined rates) membawa implikasi pada perlakuan suatu desain kebijakan moneter yang dapat mengakomodir kedua hal tersebut dan masih berada dalam suatu kerangka kebijakan moneter yang utuh. Desain kebijakan moneter dalam dual banking system di Indonesia hendaknya mengedepankan konsistensi antara instrumen syariah dengan instrumen konvensional serta memperhatikan prinsip equality terhadap kedua jenis perbankan tersebut.

Sebagai negara yang menerapkan sistem moneter ganda, Indonesia juga melakukan kebijakan moneter melalui OMS atau Operasi Moneter Syariah. Operasi Moneter Syariah (Bank Indonesia, 2015) adalah pelaksanaan kebijakan moneter oleh Bank Indonesia dalam rangka pengendalian moneter melalui kegiatan operasi pasar terbuka dan penyediaan standing facilities berdasarkan prinsip syariah. Tujuan OMS yaitu 
mencapai target operasional pengendalian moneter syariah dalam rangka mendukung pencapaian sasaran akhir kebijakan moneter Bank Indonesia.
Kegiatan OMS dilakukan dengan Operasi Pasar Terbuka Syariah dan Standing facilities Syariah. Secara lebih rinci dapat dilihat pada gambar (Bank Indonesia, 2015) di bawah berikut ini:

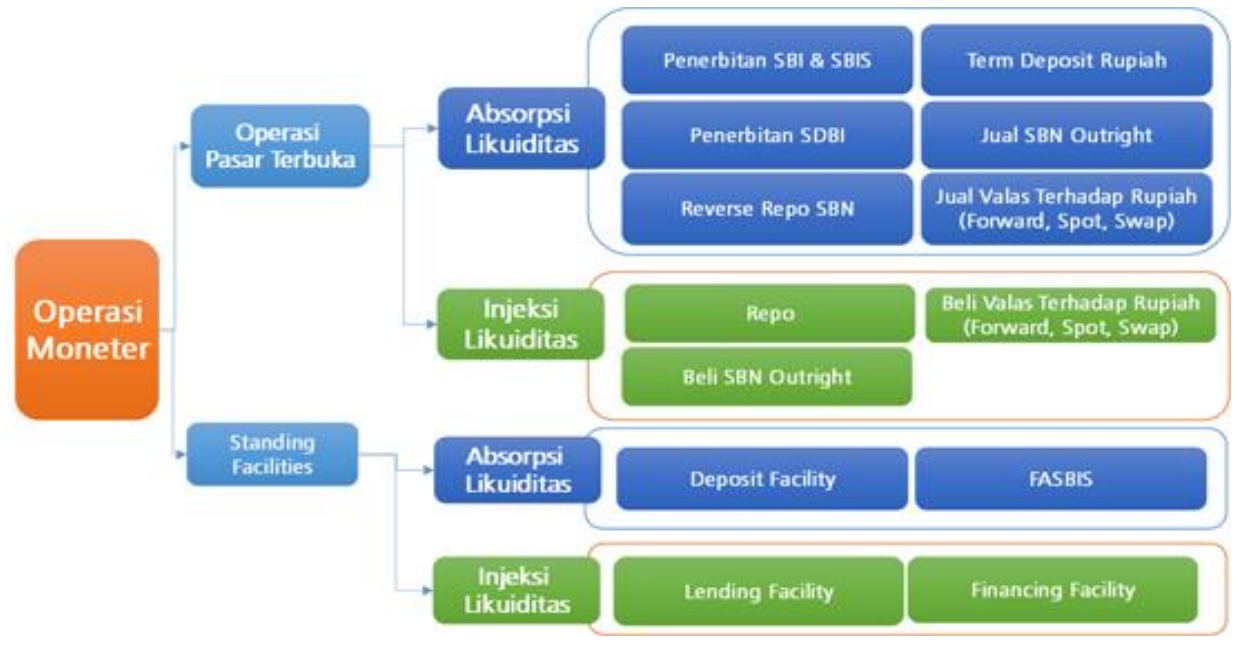

Gambar 2

Instrumen Operasi Moneter

Instrumen pengendalian moneter pada sistem ekonomi konvensional terbukti tidak efisien dan tidak lebih stabil dibandingkan dengan instrumen pengendalian moneter pada sistem ekonomi Islam (Bayuni, E.M. \& Ascarya, 2009).

Penerapan instrumen moneter syariah yang berdampingan langsung dengan instrumen moneter konvensional memiliki dampak yang cukup signifikan terhadap pengendalian inflasi (stabilitas harga) di Indonesia. Namun, sebenarnya bagaimana konstribusi instrumen moneter syariah secara parsial terhadap pengendalian inflasi belum diketahui pasti.
Oleh karena itu, mengingat sangat pentingnya mengetahui kontribusi instrumen moneter syariah, pada penelitian ini penulis khusus akan membahas tentang bagaimana kontribusi instrumen moneter syariah terhadap sasaran operasional untuk mencapai sasaran akhir pengendalian inflasi di Indonesia.

Berdasarkan uraian latar belakang di atas maka yang menjadi pokok permasalahan adalah:

1. Bagaimanakah instrumen moneter menurut syariah?

2. Bagaimanakah pengendalian inflasi menurut syariah di Indonesia? 
3. Bagaimanakah besaran kontribusi instrumen moneter syariah terhadap pengendalian inflasi di Indonesia?

Adapun tujuan dari penelitian ini adalah:

1. Untuk menjelaskan instrumen moneter menurut syariah.

2. Untuk menjelaskan pengendalian inflasi menurut syariah di Indonesia.

3. Untuk mengetahui besaran kontribusi instrumen moneter dalam syariah terhadap pengendalian inflasi di Indonesia.

Penelitian ini bersifat kuantitatif analisis, yaitu dengan menggunakan analisa kuantitatif desktiptif yaitu dengan mengorganisasi dan menganalisa data, agar dapat memberikan gambaran secara teratur, ringkas dan jelas, mengenai suatu gejala, peristiwa atau keadaan, sehingga dapat ditarik pengertian atau makna tertentu setelah diolah melalui metodologi. Selanjutnya dianalisa secara komprehensif apakah instrumen moneter syariah memiliki kontribusi yang signifikan terhadap pengendalian inflasi atau tidak.

Data yang digunakan dalam penelitian ini adalah data sekunder berupa time series bulanan 1:2011 - 12:2015 yang didapat dari Statistik Ekonomi dan Keuangan Indonesia pada Bank Indonesia (SEKI-BI). Statistik Perbankan Indonesia
(SPI-BI) dan Statistik Perbankan Syariah pada Bank Indonesia (SPS-BI).

Variabel dan definisi operasional yang akan digunakan meliputi:

1. Pencapaian kestabilan harga merupakan sasaran akhir kebijakan moneter baik melalui pendekatan harga maupun kuantitas. Dalam penelitian ini kestabilan harga atau tingkat inflasi sebagai variable yang dipengaruhi oleh besaran moneter total (Inflasi).

2. Sertifikat Bank Indonesia Syariah (SBIS) sebagai instrumen operasi moneter syariah.

3. Fasilitas Simpanan di Bank Indonesia Syariah (FASBIS) adalah fasilitas yang diberikan kepada bank syariah untuk menempatkan dananya di Bank Indonesia dalam rupiah, selanjutnya disebut dengan FASBIS.

4. Cadangan Wajib Minimum atau Giro Wajib Minimum (GWM) yaitu kewajiban bank syariah dalam rangka mendukung pelaksanaan prinsip kehati-hatian perbankan serta berperan sebagai instrumen moneter yang berfungsi mengendalikan jumlah peredaran uang, selanjutnya disebut dengan GWMS.

Permasalahan dalam penelitian ini akan dinalisis dengan menggunakan metode Simultaneous Regression Model 
(Model Regresi Simultan). Secara sederhana, Regresi Simultan menggambarkan hubungan dua arah karena (Sumodiningrat, 2007) jumlah persamaan dalam model persamaan simultan adalah sama dengan jumlah seluruh variabel terikatnya (dalam sistem persamaan simultan disebut: variabel endogen).

Berdasarkan persamaan yang terbentuk dari penelitian ini, maka model regresi simultan yang akan digunakan adalah Model Rekursif (Recursive Model).

Model Rekursif yaitu model khusus dari sistem persamaan simultan yang dapat menerapkan prosedur penaksiran dengan OLS (Ordinary Least Square).

Berdasarkan model persamaan pada penelitian ini, persamaan tersebut memenuhi asumsi prosedur OLS. Sehingga OLS dapat diterapkan langsung pada penelitian ini.

Penelitian terdahulu mengenai instrumen kebijakan moneter telah banyak dilakukan oleh para peneliti lain. Secara rinci beberapa penelitian terdahulu yang mendukung penelitian ini akan dijelaskan di bawah ini:

Tabel. 1

\section{Penelitian Terdahulu}

\begin{tabular}{|c|c|c|c|c|}
\hline No. & $\begin{array}{c}\text { Nama } \\
\text { Peneliti }\end{array}$ & Judul Penelitian & Objek Penelitian & Tahun \\
\hline 1. & $\begin{array}{l}\text { Masyitha } \\
\text { Mutiara } \\
\text { Ramadhan; } \\
\text { Irfan Syauqi } \\
\text { Beik }\end{array}$ & $\begin{array}{l}\text { Analisis Pengaruh Instrumen } \\
\text { Moneter Syariah dan Konvensional } \\
\text { Terhadap Penyaluran Dana ke } \\
\text { Sektor Usaha Mikro Kecil dan } \\
\text { Menengah (UMKM) di Indonesia }\end{array}$ & $\begin{array}{l}\text { Instrumen } \\
\text { Syariah } \\
\text { Konvensional dan } \\
\text { Penyaluran Dana ke } \\
\text { Sektor Usaha Mikro } \\
\text { Kecil dan Menengah } \\
(\text { UMKM) di Indonesia }\end{array}$ & 2013 \\
\hline 2. & $\begin{array}{l}\text { Tia } \\
\text { Enggistiani } \\
\text { Junandi }\end{array}$ & $\begin{array}{llr}\text { Efektivitas } & \text { Instrumen } & \text { Moneter } \\
\text { Syariah } & \text { Terhadap } & \text { Kinerja } \\
\text { Perbankan } & \text { Syariah Di } & \text { Indonesia } \\
\text { dengan Metode VAR/VECM }\end{array}$ & 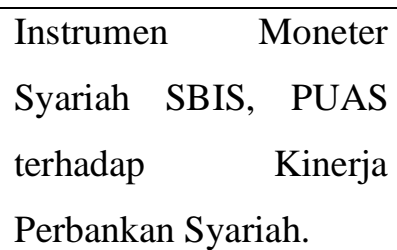 & 2013 \\
\hline
\end{tabular}




\begin{tabular}{|c|c|c|c|c|}
\hline 3. & Wulan Asnuri & $\begin{array}{l}\text { Pengaruh Instrumen Kebijakan } \\
\text { Moneter Syariah dan Ekspor } \\
\text { Terhadap Pertumbuhan Ekonomi } \\
\text { Di Indonesia }\end{array}$ & $\begin{array}{l}\text { Instrumen } r \text { Moneter } \\
\text { Syariah, SBIS, Ekspor } \\
\text { dan Pertumbuhan } \\
\text { Ekonomi }\end{array}$ & 2013 \\
\hline 4. & $\begin{array}{l}\text { Eva Misfah } \\
\text { Bayuni; } \\
\text { Ascarya }\end{array}$ & 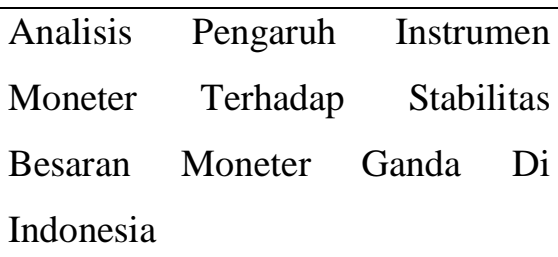 & $\begin{array}{lr}\text { SBIrate, } & \text { SBISreturn, } \\
\text { Besaran } & \text { Moneter dan } \\
\text { Indeks } & \text { Harga } \\
\text { Konsumen (IHK) }\end{array}$ & 2009 \\
\hline
\end{tabular}

\section{State of The Art}

Berdasarkan penelusuran beberapa literatur yang berkaitan dengan permasalahan tersebut diatas, dapat disimpulkan bahwa penelitian-penelitian tersebut memiliki objek penelitian yang hampir sama dengan penelitian ini yaitu mengenai instrumen moneter syariah. Sedangkan berbeda pada fokus penelitiannya yaitu pada perbankan syariah, sektor UMKM, pertumbuhan ekonomi dan juga sistem moneter ganda di Indonesia.

Adapun fokus pada penelitian yang akan dilakukan ini yaitu membahas kontribusi beberapa instrumen moneter menurut syariah terhadap pengendalian inflasi yang merupakan sasaran utama kebijakan moneter di Indonesia dengan menggunakan metode regresi simultan.

Dapat disimpulkan penelitian ini memiliki beberapa perbedaan dengan penelitian sebelumnya; pertama, variabel instrumen moneter syariah yang lebih banyak dibandingkan dengan penelitian sebelumnya; kedua, fokus penelitian yang terletak pada kontribusi instrumen moneter syariah terhadap sasaran utama kebijakan moneter yaitu inflasi; dan ketiga, metode penelitian yang digunakan juga berbeda dengan penelitian sebelumnya.

\section{PEMBAHASAN}

\section{A. Kerangka Teori}

Kebijakan moneter dengan sasaran tunggal, yaitu stabilisasi harga (pengendalian tingkat inflasi), pada umumnya menggunakan pendekatan harga. Sedangkan kebijakan moneter dengan sasaran multi, yaitu disamping stabilisasi harga juga pertumbuhan ekonomi, perluasan kesempatan kerja, dan keseimbangan neraca pembayaran, pada umumnya menggunakan pendekatan kuantitas (Siamat, 2005). 



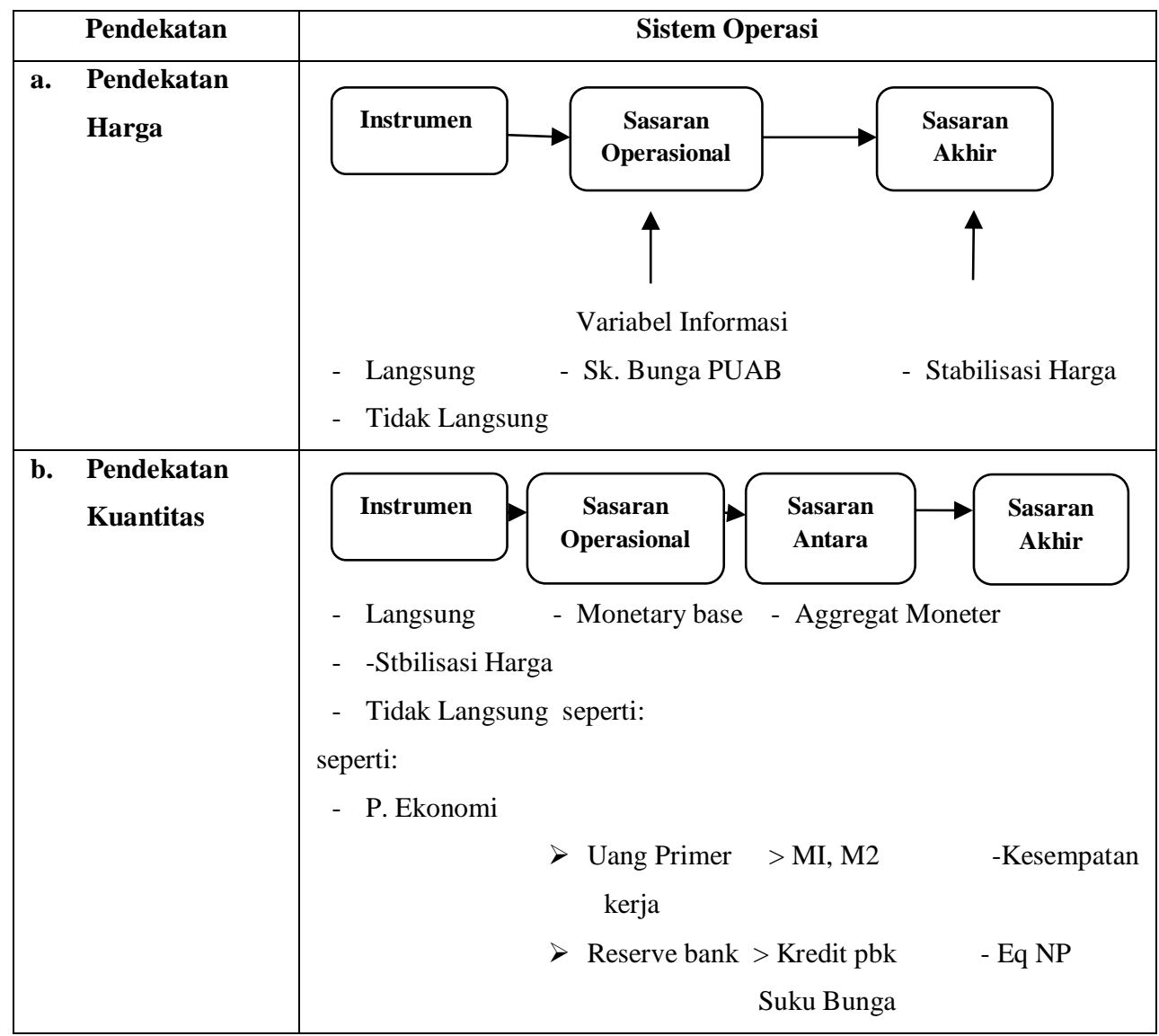

Sumber: Ascarya (2002)

\section{Gambar 3}

\section{Perbandingan Sitem Operasi Kebijakan Moneter}

Muhammad (2002) menyatakan bahwa instrumen yang dapat diterapkan dalam perekonomian Islam dapat ditempuh dengan dua instrumen besar, yaitu kontrol kuantitatif penyaluran kredit dan merealisasikan tujuan sosio ekonomi.

Kontrol kuantitaif penyaluran kredit didukung dengan instrumen berupa: statutory reserve requirement; credit ceiling; government deposits; common pool; moral suasion; equity-base instrumens; dan change in the profit and loss sharing ratio. Sementara itu, merealisasikan tujuan sosio-ekonomi adalah dengan treating the created money as fay; dan goal oriented allocation of credit.

\section{B. Instrumen Pengendalian Moneter Syariah}

1. Mazhab Pertama (Iqtishaduna)

Pada masa awal Islam (Karim, 2007) dapat dikatakan bahwa tidak diperlukan suatu kebijakan moneter dikarenakan hampir tidak adanya sistem perbankan dan minimnya penggunaan uang. Jadi tidak ada alasan yang memadai untuk melakukan perubahan-perubahan 
terhadap penawaran uang $\left(\mathrm{M}^{\wedge} \mathrm{s}\right)$ melalui kebijakan diskresioner. Selain itu, kredit tidak memiliki peran dalam penciptaan uang, karena kredit hanya digunakan diantara para pedagang saja serta peraturan pemerintah tentang surat peminjaman (promissory notes) dan instrumen negosiasi (negotible instruments) dirancang sedemikian rupa sehingga tidak memungkinkan sistem kredit tersebut menciptakan uang.

Promissory Notes atau Bill of Exchange dapat diterbitkan untuk membeli barang dan jasa ataupun untuk mendapatkan sejumlah dana segar, namun surat tersebut tidak dapat dimanfaatkan untuk tujuan kredit. Kreditor dapat menjual surat tersebut akan tetapi debitur tidak dapat menjual uang ataupun komoditi sebelum ia menerima surat tersebut. Karena itulah tidak ada pasar untuk jual beli negotiable instruments, spekulasi dan penggunaan pasar uang menjadi tidak ada. Jadi sistem kredit tidak menciptakan uang.

Aturan-aturan tersebut memenuhi keseimbangan antara pasar dan pasar uang berdasarkan transaksi tunai. Dalam nasi'a atau aturan transaksi Islam lainnya, pada saat komoditi dibeli saat ini sedangkan pembayarannya dilakukan kemudian, uang yang dibayarkan atau diterima untuk mendapatkan komoditas atau jasa. Dengan kata lain, uang dipertukarkan dengan sesuatu yang benar-benar memberikan nilai tambah nilai tambah bagi perekonomian. Transaksi lainnya seperti judi, riba, jual-beli superficial promissory notes dilarang dalam Islam sehingga keseimbangan antara arus uang dan barang atau jasa dapat dipertahankan. Jika diperhatikan dengan seksama, maka tampak bahwa perputaran uang dalam periode tertentu sama dengan nilai barang dan jasa yang diperlukan pada rentang waktu yang sama.

Instrumen lain yang digunakan pada saat ini untuk mengatur jumlah peredaran uang serta mengatur tingkat suku bunga jangka pendek yaitu Open Market Operation (melalui jual beli surat berharga pemerintah) jelas belum ada pada masa awal perkembangan Islam. Selain itu, jelas tindakan menaikan atau menurunkan tingkat suku bunga tersebut bertentanga dengan ajaran Islam karena adanya laranganyang berkenaan dengan riba dalam Islam itu sendiri.

\section{Mazhab Kedua (Mainstream)}

Tujuan kebijakan moneter dalam Karim (2007) yang diberlakukan oleh pemerintah adalah maksimalkan sumber daya (resources) yang ada agar dapat dialokasikan pada kegiatan perekonomian yang produktif. Di dalam Al Qur'an sudah 
jelas bahwa kita dilarang untuk melakukan penumpukan uang (money hoarding) yang pada akhirnya akan menjadikan uang tersebut tidak memberikan manfaat terhadap peningkatan kesejahteraan masyarakat secara keseluruhan. Kekayaan yang iddle tersebut akan menjadikan sumber dana yang pada awalnya bersifat produktif menjadi tidak produktif. Oleh sebab itu, mazhab kedua ini merancang sebuah instrumen kebijakan yang ditujukan untuk mempengaruhi besar kecilnya permintaan uang $\left(\mathrm{M}^{\wedge} \mathrm{D}\right)$ agar dapat dialokasikan pada peningkatan produktivitas perekonomian secara keseluruhan.

Permintaan dalam Islam dikelompokan dalam dua motif, yaitu motif transaksi (transaction motive) dan motif berjaga-jaga (precautionary motive) semakin banyak uang yang idle, maka berarti permintaan uang untuk berjaga-jaga ( M_prec ${ }^{\wedge} \mathrm{D}$ ) semakin besar, sedangkan semakin tinggi pajak yang dikakan terhadap uang yang idle berbaring terbalik dengan permintaan uang untuk berjagajaga. Dues of idle find adalah instrument kebijakan uang dikenakan pada semua aset produktif uang iddle.

Apabila permintaan uang ditujukan untuk berjaga-jaga meningkatkan ( $\left.\mathrm{M} \_\operatorname{prec}^{\wedge} \mathrm{D} \uparrow\right)$, maka usaha yang dilakukan pemerintah untuk mengembalikan permintaan uang $\left(\mathrm{M}^{\wedge} \mathrm{D}\right)$ pada titik keseimbangan (equilibrium) adalah dengan cara meningkatkan dues of iddle fund. Semakin tinggi dues of fund yang dikenakan terhadap uang yang iddleakan menyebabkan masyarakat enggan untuk tetap menyimpan uang yang iddle tersebut. Konsekuensinya masyakat yang mempunyai uang iddle akan secara sukarela mengalokasikan kekayaannya pada investasi yang sifatnya produktif.

Instrumen dues of idle fund juga dapat digunakan untuk memenuhi permintaan agregatif (AD). Kebijakan yang ditujukan untuk meningkatkan permintaan Agregatif (AD) atau untuk mendorong laju pertumbuhan pendapatan nasional dapat dialkukan dengan cara meningkatkan dues of iddle fund.

Peningkatan duesof idle fund akan mengalihkan permintaan uang yang sedianya ditujukan untuk penimbunan uang/aset yang produktif kepada tujuan penggunaan uang yang akan meningkatkan produktivitas uang tersebut di sektor riil, sehingga investasi akan meningkat. Peningkatan investasi tertentu saja akan berdampak pada peningkatan permintaan Agregatif (AD), sehingga keseimbangan umum yang baru akan beredar pada tingkat pendapatan nasional yang lebih tinggi. 


\section{Mazhab Ketiga (Alternatif)}

Mazhab ketiga ini menurut Karim (2007) sangat banyak dipengaruhi oleh pemikiran-pemikiran ilmiah dari Dr.M.A Choudhury. Sistem yang kebijakan moneter yang dianjurkan oleh mazhab ini adalah syuratiq process yaitu di mana suatu kebijakan yang diambil oleh otoritas moneter adalah berdasarkan musyawarah sebelumnya dengan otoritas sektor riil. Jadi keputusan-keputusan kebijakan moneter yang kemudian dituangkan dalam bentuk instrumen moneter biasanya adalah harmionisasi dengan kebijakan-kebijakan di sektor riil.

Sementara itu, menurut Umer Chapra (1985) mengemukakan instrumenInstrumen pengendalian moneter perkonomian Islam, terdiri dari:

a. Target Pertumbuhan dalam $\mathrm{M}$ dan $\mathrm{M}_{\mathrm{o}}$.

b. Saham Publik terhadap Deposito Unjuk (Uang Giral).

c. Cadangan Wajib Resmi/GWM .

d. Alokasi Kredit yang Berorientasi kepada Nilai.

e. Pembatas Kredit.

\section{Penerapan Instrumen Moneter Syariah di Beberapa Negara}

Sementara itu, penerapan instrumeninstrumen pengendalian moneter syariah berbeda pada masing-masing negara. Termasuk juga pada negara yang muslim, maupun negara dengan sistem moneter ganda.

Pada masa sebelum diberlakukannya syariat Islam (Karim, 2007) pada sistem perbankan di Sudan, Bank Sentral Sudan (BOS) sangat tergantung pada instrumeninstrumen langsung seperti tingkat suku bunga, plafon kredit (credit ceiling), ketentuan rasio likuiditas (statutora liquidity ratio), dan tingkat diskonto. Pada awalnya instrumen-instrumen tersebut sangat efektif karena perekonomian Sudan yang mempunyai karakteristik yaitu sistem finansial yang non-kompretitif, pasar model primer dan sekunder yang belum berkembang, serta kelangkaan mpodal. Namun karena instrumen-instrumen langsung tersebut mengakibatkan distorsi dari lokasi sumber daya bank, interferensi terhadap mekanisme harga, pembatasan kredit, serta mislokasi dan distorsi dari kompetisi akibat penerapan batasanbatasan pada manajemen aset bank. Pada akhirnya, BOS lebih memilih untuk memakai instrumen-instrumen tidak langsung seperti RR dan OMO.

Pada tahun 1984, setelah diperkenalkannya syariah Islam di Sudan, BOS mengeluarkan arahan dan perintah kepada seluruh bank yang beroperasi di sudan agar menjalankan prinsip-prinsip perbankan yang sesuai dengan syariat Islam dalam aktivitas kesehariannya. 
Akibatnya, BOS dihadapkan pada permasalahan subsitusi instrumen moneter konvensional dengan instrumen moneter yang sesuai dengan syariat Islam untuk dapat mempertahankan perannya sebagai pengawas dan pemberi arahan bagi bankbank, melakukan ekspansi atau kontraksi penawaran uang atau kredit, dan meimplementasikan kebijakan moneter, serta sekaligus menjaga kepentingan publik.

Instrumen moneter syariah yang digunakan oleh Sudan dalam Ascarya (2007) dalam operasional bank sentralnya adalah sebagai berikut:

1. Central Bank Musharaka Certificates (CMCs)

2. Goverment Musharaka Certificates (GMCs)

3. Goverment Investment Certificates (GICs)

\section{Foreign Exchange}

Selain itu, dalam Ascarya (2007) dijelaskan pula instrumen moneter syariah yang digunakan oleh negara dengan sistem moneter ganda yaitu Pakistandan Malaysiadalam operasional bank sentralnya, sebagai berikut:

1. Mudharaba Certificate

2. Participation Term Certificate (PTCs)

3. Certificate of Musharika (COMs)

4. Term Finance Certificate (TFCs)
Di Malaysia, (Ascarya, 2007) penggunaan $b a$ 'I al 'inah (jual beli dengan janji akan membelinya kembali) diperbolehkan. Penggunaan akad $b a{ }^{\prime} i$ al inah mendorong semakin banyaknya instrumen yang digunakan. Yaitu sebagai berikut:

1. Government Investment Issues-i

2. Malaysian Islamic Treasury Bills

3. Bank Negara Negotiable Notes-i

4. Cagamas Papers

5. Commercial Papers- $i$

6. Negotiable Debt Certificate- $i$

7. Negotiable Instrumen of Deposits-i

8. Sell and Buy Back Agreements (Repo-i)

9. Foreign Exchange

10. Promissory FX Contract- $i$

Untuk mencapai sasaran akhir yang diinginkan sebagaimana telah dijelaskan sebelumnya, BI sebagai otoritas moneter selanjutnya melakukan perencanaan dan penyusunan program kebijakan pengendalian uang beredar, baik kebijakan moneter yang mengarah pada kebijakan pengetatan atau kontraksi moneter maupun kebijakan ekspansi. Pelaksanaan kebijakan pengendalian jumlah uang beredar tersebut sangat tergantung pada kondisi uang beredar dan arah kebijkan moneter BI (Siamat, 2005). 


\section{Instrumen Pengendalian Moneter Syariah Di Indonesia}

Untuk mempengaruhi jumlah uang beredar, BI menggunakan beberapa Instrumen pengendalian moneter baik langsung maupun tidak langsung.

a. Instrumen pengendalian moneter langsung

- Penurunan nilai uang

- Kredit langsung

b. Instrumen pengendalian moneter tidak langsung

- Giro Wajib Minimum

- Fasilitas Diskonto (Tingkat Suku Bunga)

- Operasi Pasar Terbuka (OPT)

Meliputi tindakan menjual dan membeli surat-surat berharga oleh bank sentral (Nopirin, 2000). Berikut beberapa instrumen yang digunakan dalam Operasi Pasar Terbuka di Indonesia, yaitu:

- Sertifikat Bank Indonesia (SBI)

- Sertifikat Bank Indonesia Syariah (SBIS)

- Surat Berharga Pasar Uang (SBPU)

- Reverse Repo - Sertifikat Bank Syariah Negara (RR-SBSN)

- Sertifikat Deposito

- Commercial Paper

- Call Money

- Wesel dan Promes
- Repurchase Agreement

- Bill of Exchange

- Banker's acceptance

- Fasilitas Simpanan Bank Indonesia (FASBI)

- Imbauan Moral

Perkembangan industri perbankan syariah di Indonesia, menjadi keunggulan tersendiri bagi sistem perekonomian Indonesia. Sebagai otoritas moneter tertinggi BI telah menetapkan beberapa Instrumen pengendalian moneter syariah yang mengontrol keberlangsungan industri perbankan syariah. Beberapa instrumen yang ditetapkan merupakan instrumen yang memiliki fungsi sama seperti pada sistem perbankan konvensional. Akan tetapi kebijakan-kebijakannya ditetapkan sesuai dengan ketentuan syariah.

Berikut ini adalah pengertian instrumen-instrumen moneter syariah yang diterapkan di Indonesia;

1. SBIS Sertifikat Bank Indonesia Syariah yang selanjutnya disingkat SBIS adalahsurat berharga berdasarkan prinsip syariah berjangka waktu pendekdalam mata uang Rupiah yang diterbitkan oleh Bank Indonesia.

2. Reverse RepoSurat Berharga Syariah Negara yang selanjutnya disingkat RRSBSN, ataudapat disebut Sukuk Negara, adalah surat berharga negara yangditerbitkan berdasarkan prinsip 
syariah, sebagai bukti atas bagianpenyertaan terhadap aset SBSN dalam mata uang Rupiah.

3. Fasilitas Simpanan Bank Indonesia Syariah yang selanjutnya disingkat FASBIS adalah fasilitas yang disediakan oleh Bank Indonesia kepada bank umum syariah, unit usaha syariah pialang pasar uang rupiah dan valas untuk menempatkan dananya di Bank Indonesia dalam bentuk Rupiah.

4. Adapun Giro Wajib Minimum (GWM) pada bank syariah ditetapkan sesuai dengan ketetapan BI dan Imbauan Moral (Moral Suassion) untuk perbankan syariah kurang lebih memiliki pengertian yang sama dengan yang dilakukan BI terhadap perbankan konvensional.

5. PUAS atau Pasar Uang Antar Bank Syariah adalah kegiatan pinjam meminjam dana antara satu bank yang memiliki kelebihan likuiditas dengan bank lainnya yang membutuhkan likuiditas. Transaksi PUAS dapat berjangka waktu dari satu hari kerja (overnight) sampai dengan satu tahun.

\section{E. Instrumen Pengendalian Inflasi}

\section{Menurut Syariah Di Indonesia}

Menurut para ekonom Islam, Al Masri dalam Karim (2007) menyimpulkan
Inflasi berakibat buruk bagi perekonomian karena:

1. Menimbulkan gangguan terhadap fungsi uang, terutama terhadap fungsi tabungan (nilai simpan), fungsi dari pembayaran di muka, dan fungsi dari unit perhitungan.

2. Melemahkan semangat menabung dan sikap terhadap menabung dari masyarakat.

3. Meningkatkan kecenderungan untuk berbelanja terutama non-primer dan barang-barang mewah.

4. Mengarahkan investasi pada hal-hal yang non produktif yaitu penumpukan kekayaan seperti: tanah, bangunan, logam mulia, mata uang asing dengan mengorbankan investasi ke arah produktif seperti: pertanian, industrial, perdagangan, transportasi dan lainnya.

Ekonom Islam, Taqiuddin Ahmad ibn al Maqrizi (1364-1441 M) dalam Bayuni (2012) menggolongkan inflasi dalam dua golongan yaitu:

\section{Natural Inflation (Inflasi Alamiah)}

Sesuai dengan namanya, inflasi jenis ini disebabkan oleh berbagai faktor alamiah yang tidak bisa dihindari umat manusia. Menurut Al Maqrizi, ketika suatu bencana alam terjadi, berbagai bahan makanan dan hasil bumi lainnya mengalami gagal panen, sehingga persediaan barang-barang 
tersebut mengalami penurunan yang sangat drastis dan terjadi kelangkaan. Di lain pihak, karena sifatnya yang sangat signifikan dalam kehidupan, permintaan terhadap berbagai barang itu mengalami peningkatan. Harga-harga membumbung tinggi jauh melebihi daya beli masyarakat. Hal ini, sangat berimplikasi terhadap kenaikan harga berbagai barang dan jasa lainnya. Inflasi alamiah menurut $\mathrm{Al}$ Maqrizi dapat dibedakan menjadi dua jenis yaitu:

a. Akibat uang yang masuk dari luar negeri terlalu banyak (umumnyaberbentuk uang cash atau aset tidak produktif lainnya seperti barang-barang mewah), di mana ekspor naik sedangkan impor cenderung turun atau tetap, sehingga mengakibatkan net ekspor nilainya menjadi sangat besar, maka akan berakibat pada naiknya permintaan agregat. Dengan demikian, naiknya permintaan agregat tersebut mengakibatkan kenaikan pada tingkat harga secara umum.

b. Akibat dari turunnya tingkat produksi karena terjadinya paceklik, perang ataupun embargo ekonomi yang kemudian berimbas pada kenaikan tingkat harga.

2. Human Error Inflation (Inflasi Karena Kesalahan Manusia)
Selain faktor alam, Al Maqrizi menyatakan bahwa inflasi dapat terjadi akibat kesalahan manusia. Ia telah mengidentifikasi tiga hal yang baik secara sendiri-sendiri maupun bersama-sama menyebabkan terjadinya inflasi ini. Ketiga faktor tersebut yaitu sebagai berikut:

a. Korupsi dan administrasi yang buruk,

b. Pajak yang berlebihan,

c. Dan peningkatan sirkulasi mata uang fulus.

Dalam melaksanakan kebijakan moneter, Bank Indonesia menganut sebuah kerangka kerja yang dinamakan Inflation Targeting Framework (ITF). Kerangka kerja ini diterapkan secara formal sejak Juli 2005, setelah sebelumnya menggunakan kebijakan moneter yang menerapkan uang primer (base money) sebagai sasaran kebijakan moneter. Ada dua jenis kebijakan moneter yang dilakukan di Indonesia, kebijakan ekspansif dan kebijakan kontraktif.

Kebijakan Ekspansif (Monetary Expansive Policy) adalah suatu kebijakan dalam rangka menambah jumlah uang yang beredar. Kebijakan ini dilakukan untuk mengatasi pengangguran dan meningkatkan daya beli masyarakat (permintaan masyarakat). Kebijakan ini diterapkan pada saat perekonomian 
mengalami resesi atau depresi. Kebijkan moneter ekspansif ini disebut juga sebagai kebijakan moneter longgar (easy monetary policy).

1. Politik diskonto (penurunan tingkat suku bunga)

2. Politik pasar terbuka (pembelian suratsurat berharga, misalnya saham dan obligasi)

3. Politik cash ratio (penurunan cadangan kas)

4. Politik kredit selektif (pemberian kredit longgar).

Kebijakan Kontranktif (Monetary Contractive Policy) adalah kebijakan yang dilakukan dalam rangka mengurangi jumlah uang yang beredar. Kebijakan ini dilakukan pada saat perekonomian mengalami inflasi. Kebijakan moneter kontraktif disebut juga dengan uang ketat (tight money policy).

1. Politik pasar terbuka (penjualan surat berharga, misalnya saham dan obligasi)

2. Politik cash ratio (peningkatan cadangan kas)

3. Politik kredit selektif (pengetatan pemeberian kredit)

Kedua jenis kebijakan moneter tersebut akan dilakukan untuk mengendalikan inflasi di Indonesia. Pada pelaksanaan kebijakan ekspansif dan kontraktiflah instrumen-instrumen moneter akan berperan penting. Kecuali pada jenis kebijakan moneter yang berkaitan dengan tingkat bunga, instrumen-instrumen moneter syariah aktif diterapkan untuk mengendalikan inflasi.

Pada saat perekonomian sedang mengalami inflasi, maka yang dilakukan adalah kebijakan kontraktif. Salah satu instrumen yang diterapkan adalah penjualan surat berharga. Bank Indonesia melalui Operasi Pasar Terbuka melakukan penjualan Sertifikat Bank Indonesia (SBI) dan Sertifikat Bank Indonesia Syariah (SBIS) sebagai Operasi Moneter Syariahnya (OMS). Sebaliknya, apabila perekonomian sedang lesu dan perekonomian masyarakat melemah, Bank Indonesia akan melakukan kebijakan ekspansif. SBI dan SBIS yang berada di tangan masyarakat akan dibeli kembali. Dengan demikian, uang yang beredar di masyarakat bertambah dan diharapkan dapat menggairahkan kembali perekonomian masyarakat.

Pengendalian terhadap inflasi dilakukan dengan melakukan kebijakankebijakan moneter melalui instrumeninstrumen moneter sebagai alatnya. Instrumen-instrumen moneter syariah yang diterapkan di Indonesia merupakan ciri kebijakan moneter ganda yang dilakukan oleh Bank Indonesia, dimana pelaksanaannya berbarengan dengan 
instrumen-instrumen

moneter

konvensional.

\section{F. Analisis Kontribusi Instrumen \\ Moneter Syariah Terhadap \\ Pengendalian Inflasi Di Indonesia}

1. Analisis SBIS terhadap Inflasi analisis peesamaan kontribusi instrumen moneter syariah terhadap inflasi secara parsial. Berikut adalah analisis persamaan kontribusi instrumen moneter syariah terhadap inflasi secara parsial:

Tabel 2

Analisis SBIS Terhadap Inflasi

\begin{tabular}{|l|c|c|c|}
\hline & R-squared & Coefficient & Sig \\
\hline \multirow{2nnyy}{*}{ SBIS } & \multirow{2}{*}{0,182504} & 1,489154 & 0,0007 \\
\cline { 1 - 3 } C & & $-6,641724$ & 0,0617 \\
\hline
\end{tabular}

Hasil pengolahan menunjukkan nilai significancy 0,0007 dimana $<0,05$ dimana $\mathrm{H}_{0}$ ditolak. Artinya, Terdapat kontribusi SBIS terhadap Inflasi. Hasil juga menunjukkan R-Squared sebesar 0,182504 atau $18 \%$ yang artinya variabel SBIS memiliki kontribusi yang sangat lemah terhadap Inflasinamun dengan nilai kontribusi cukup besar 1,489154 atau $149 \%$ secara parsial. Sama halnya dengan 2. Analisis FASBIS terhadap Inflasi
M2 terhadap Inflasi, meskipun nilai kontribusi yang dihasilkan oleh persamaan ini cukup besar, yang perlu diperhatikan adalah kekuatan kontribusinya yang sangat lemah, sehingga hal tersebut tidak cukup berpengaruh bagi persamaan ini.

Dengan demikian, maka dapat disimpulkan hasil estimasi bagi persamaan ini yaitu sebagai berikut:

Inflasi $=-6,641724+1,489154$ SBIS

Tabel 3

Analisis FASBIS Terhadap Inflasi

\begin{tabular}{|l|c|c|c|}
\hline & R-squared & Coefficient & Sig \\
\hline FASBIS & \multirow{2}{*}{0,009450} & 0,391824 & $\mathbf{0 , 4 6 0 0}$ \\
\cline { 1 - 3 } C & & 2,245375 & $\mathbf{0 , 6 4 8 3}$ \\
\hline
\end{tabular}

Hasil pengolahan menunjukkan nilai significancy 0,46 dimana $>0,05$ dimana $\mathrm{H}_{0}$ diterima. Artinya, tidak terdapat kontribusi FASBIS terhadap Inflasi. Hasil juga menunjukkan R-Squared sangat kecil yaitu sebesar 0,009450 atau 9,4\% yang artinya apabila variabel FASBIS memiliki kontribusi, maka kontribusi tersebutsangat lemah pengaruhnya terhadap Inflasi.Oleh 
karena itu, untuk model ini tidak dapat dihasilkan estimasi persamaannya.

3. Analisis GWMS terhadap Inflasi

Tabel 4

Analisis GWMS Terhadap Inflasi

\begin{tabular}{|l|c|c|c|}
\hline & R-squared & Coefficient & Sig \\
\hline GWMS & \multirow{2}{*}{0,146525} & 1,778933 & 0,0025 \\
\cline { 1 - 3 } C & & $-1,015513$ & 0,0506 \\
\hline
\end{tabular}

Hasil pengolahan menunjukkan nilai significancy 0,0025 dimana $<0,05$ dimana $\mathrm{H}_{0}$ ditolak. Artinya, terdapat kontribusi GWMS terhadap Inflasi. Hasil juga menunjukkan R-Squared sebesar 0,146525 atau $15 \%$ yang artinya variabel GWMS memiliki kontribusi yang sangatlemah terhadap Inflasi dengan nilai kontribusi yang cukup besar 1,778933 atau $178 \%$ secara parsial. Meskipun nilai kontribusi yang dihasilkan cukup besar, yang perlu diperhatikan adalah kekuatan kontribusinya yang sangat lemah, sehingga hal tersebut tidak cukup berpengaruh bagi persamaan ini.

Dengan demikian, maka dapat disimpulkan hasil estimasi bagi persamaan ini yaitu sebagai berikut:

Inflasi $=-1,015513+1,778933$ GWMS

Hasil analisis terhadap model persamaan kontribusi instrumen moneter syariah terhadap Inflasi menunjukkan beberapa kontribusi yang signifikan kecuali pada persamaan FASBIS terhadap Inflasi. Di antara instrumen moneter syariah yang memiliki kontribusi, SBIS merupakan instrumen yang memiliki kontribusi (signifikan) dengan R-Squared $18 \%$ (sangat lemah) dan nilai kontribusi cukup besar yaitu 149\%.

\section{SIMPULAN}

Instrumen-instrumen moneter syariah yang diterapkan di Indonesia yaitu Sertifikat Bank Indonesia Syariah (SBIS), Reverse Repo Surat Berharga Syariah Negara, Fasilitas Simpanan Bank Indonesia Syariah (FASBIS), Giro Wajib Minimum (GWM) pada Bank Syariah dan PUAS atau Pasar Uang antar Bank Syariah.

Pengendalian Inflasi di Indonesia menurut Syariah yaitu dengan menggunakan intrumen-instrumen moneter syariah yang memiliki fungsi untuk mengatur jumlah uang beredar (M2) yang sesuai dengan industri perbankan syariah di Indonesia. Oleh karena itu kebijakan moneter dalam rangka mengendalikan inflasi di Indonesia juga dilakukan dengan 
instrumen moneter syariah. Baik kebijakan moneter ekspansif maupun kontraktif.

Kontribusi instrumen-instrumen moneter syariah terhadap pengendalian inflasi di Indonesia masih sangat kecil. Hal ini berdasarkan hasil pengolahan pada penelitian ini bahwa instrumen moneter hanya beberapa model yang berkontribusi. Nilai kontribusi yang dihasilkan pun sangat kecil dengan skala penilaian $R$ Squared berkisar sangat lemah dan atau lemah.

Instrumen-instrumen moneter syariah di Indonesia masih relatif lebih sedikit jumlahnya dibandingkan dengan instrumen moneter syariah di negaranegara dengan sistem moneter ganda lainnya. Oleh karena itu kedepannya lebih ditingkatkan variasi instrumen moneter syariah yang dapat diterapkan di Indonesia.

Pengendalian inflasi menurut syariah di Indonesia masih sangat bergantung terhadap kebijakan moneter yang menerapkan instrumen moneter konvensional dan syariah secara bersamaan. Berdasarkan hal itu kontribusi instrumen moneter syariah terhadap inflasi masih sangat kecil. Sebaiknya instrumen moneter syariah pada penerapannya mampu berdiri sendiri dan tidak hanya sebagai pelengkap instrumen konvensional.
Kontribusi instrumen-instrumen moneter syariah yang masih sangat kecil, sangat berkaitan erat dengan industri perbankan dan atau keuangan syariah di Indonesia. Dengan demikian pentingnya untuk meningkatkan market share industri perbankan dan atau keuangan syariah bukan semata-mata hanya sebagai sosialisasi perbankan dan keuangan syariah saja. Akan tetapi, dengan adanya peningkatan market share pada industri perbankan syariah diharapkan dalam jangka panjang mampu memberikan kontribusi yang lebih besar bagi pengendalian inflasi di Indonesia.

\section{DAFTAR PUSTAKA}

Ascarya. (2002). Seri Kebanksentralan:

\section{Instrumen-Instrumen}

Pengendalian Moneter. Jakarta:

Bank Indonesia. (2007).Akad Dan Produk Bank Syariah, Jakarta: Rajawali Pers.

Asnuri, W. (2013). Pengaruh instrumen moneter syariah dan ekspor terhadap pertumbuhan ekonomi di Indonesia. Al Iqtishad, 5(2), 275288.

Bank Indonesia. (2015). Tujuan Kebijakan Moneter (online) (www.bi.go.id/id/moneter/tujuankebijakan/Contents/Default.aspx diakses 30 Nopember 2015). 
(2015). Koordinasi

Pengendalian

Inflasi

(online)http://www.bi.go.id/id/mo

neter/koordinasi-

pengendalianinflasi/Contents/Def

$\underline{\text { ault.aspx }}$

. (2015). Penjelasan

Operasi Moneter (online)

http://www.bi.go.id/id/moneter/op

erasi/penjelasan/Contents/Default.

$\underline{\operatorname{aspx}}$

(2015). Peraturan Bank

Indonesia Nomor 16/12/PBI/2014

Tentang Operasi Moneter Syariah

(online)

http://www.bi.go.id/id/peraturan/m

oneter/Pages/pbi_161214.aspx

Bayuni, E.M. \& Ascarya. (2009). Analisis

pengaruh instrumen moneter

terhadap stabilitas besaran

moneter ganda di Indonesia.

Tazkia Islamic Finance \&

Business Review, 5(1), 76-100.

Chapra, M. Umer. (1985). Sistem Moneter

Islam. Terjemahan Ikhwan Abidin

B, (2000). Jakarta: Gema Insani

Press.

Departemen Perbankan Syariah. Bank

Indonesia (2015). Laporan

Perkembangan Perbankan

Syariah.

http://www.bi.go.id/id/publikasi/p erbankan-dan-

stabilitas/syariah/Default.aspx

Junandi, T.E. (2013). Efektivitas instrumen moneter syariah terhadap kinerja perbankan syariah di Indonesia dengan metode VAR/VECM. Ekspansi, 5(2), 167-188.

Karim, Adiwarman A. (2007). Ekonomi Makro Islami. Jakarta: Rajawali Pers. Edisi Kedua

Muhammad (2002). Kebijakan Moneter dan Fiskal dalam Ekonomi Islami. Jakarta: Salemba Empat.

Nopirin. (2000). Ekonomi Moneter. Yogyakarta: BPFE - Yogyakarta.

Srisusilawati, P. (2017). Kajian komunikiasi pemasaran terpadu dalammendorong keputusan pembelian jasa perbankan.amwalun Vol. 1 No. 1 (2017): 1-18

Ramadhan, M.M. \& I.S. Beik. (2013). Analisis pengaruh instrumen moneter syariah dan konvensional terhadap penyaluran dana ke sektor usaha mikro kecil dan menengah di Indonesia. $A l$ Muzara'ah, 1(2), 175-190.

Siamat, D. (2005). Manajemen Lembaga Keuangan Kebijakan Moneter dan Perbankan. Jakarta: Lembaga 
Penerbit Fakultas Ekonomi Sumodiningrat, Gunawan. (2007). Universitas Indonesia. Ekonometrika Pengantar. Yogyakarta: BPFE - Yogyakarta. 